\title{
Functions and Role of Social Studies Teachers in the Disruption and Abundance Era
}

\author{
$1^{\text {st }}$ Huriah Rachmah \\ Bandung Islamic University \\ Indonesia \\ huriahrachmah@gmail.com
}

\author{
$2^{\text {nd }}$ Rudy Gunawan \\ Muhammadiyah University of Prof. Dr. Hamka Jakarta \\ Indonesia
}

\begin{abstract}
The purpose of writing this paper is to look at the function and role of social studies teachers in an era of disruption and abundance. The era of disruption and abundance demands a paradigm shift in producing graduates. A teacher must be able to prepare students to be great people and be able to adjust to the era in which he will take part. Innovative ways of teaching and learning, student-centered learning, the use of technology with unlimited reach, and unlimited access to new knowledge should be developed in education in Indonesia. Novelty can be obtained by various approaches in learning activities, so that the teacher must have comprehensive knowledge about religion, science and social humanities in order to build strong character of students, not give up easily in the face of all changes instead more adaptable or even become agents of change with give new ideas. In order for students to get the knowledge and skills that are able to help them face the era of disruption and the era of abundance, the teacher needs to change the way of teaching in accordance with their roles and functions. Learning can be done using the principle of connectivity so that it is able to present a learning model that recognizes major changes in society because learning is no longer an internal activity but can be done outside of oneself.
\end{abstract}

Keywords: disruption, abudance era

\section{INTRODUCTION}

The rapid development of technology forces people to continue to adjust to radical changes. These changes occur in various sectors such as correspondence that was through writing letters and sent via post office using stamps, then slowly turning into short messages via pagers and sms, e-mail and at this time, correspondence can be done easily using a smartphone. Disruption that occurs causes human replacement by the engine. The most obvious example is that toll gate guards have been replaced with e-money cards.

Rhenald Kasali [1] describes the acceleration of technology has occurred so foreseen in 2030 an employee who lost his job in the whole world about 2 billion people. This occurs because the technology replaces human labor, so that jobs which are well known as the postman, penerjamah, librarians, motorcycle taxi rank, a cashier, a newspaper deliveryman even lecturers will disappear replaced by technology.

However, the existence of technology also provides new jobs and new challenges, so the challenge must be answered because there will be an era of abundance, which is characterized by free economy and sharing economy. We have enjoyed examples of the Free Economy such as sending free letters, free long distance calls (eg WA calls), free e-books, free movies and music (youtube) and many other technology products that can be enjoyed free of charge [2]. Quoting Peter Diamandis [2] exponentially this technological progress through 6 stages is called "6D of Exponential Growth", namely:

a. Digitalization is the transfer of analog to digital technology that occurs in almost all sectors.

b. Deception conditions where humans do not feel disturbed by the transformation because it was considered not influential until its growth reaches a point of weakness.

c. This disruption is called the leap point and destabilizes the security and reliability of most employees. In Indonesia it is currently entering this stage, so that thousands of people and companies that are not capable of being panic panic

d. Dematerialization is a condition of the loss of a physical container because it is stored in "cloud" storage. For example, documents initially require paper, switch functions to less paper, then no longer stored in a flashdisk or hard disk

e. Demonetization of conditions where all data is increasingly accessible because the data storage area is getting bigger, the impact is that all costs fall dramatically due to cutting distribution channels and unnecessary costs.

f. Democratization of all things such as books, music, films and various information is abundant and many are free or low-cost so that Abundance occurs. 
Teachers should realize that knowledge has become an important element in economic development and job creation. Therefore the teacher must know some common things from knowledge-based workers in the digital era namely [6]:

a. Usually works in small companies (less than 10 people)

b. Sometimes have your own business and create your own work. Often work on a contract basis (entrepreneur) so often change jobs.

c. The nature of work often changes to respond to market developments and technology

d. Digital smart and digital technology are often the main components.

e. There are many roles played in his work considering that he only works in a small company or entrepreneurship so that many of his skills are for example as marketers, designers, salespeople, accountants or business managers.

f. Depends on informal social networking and follows the latest developments that are trending in accordance with the field of science they have.

g. Continuously learn to stay superior in the work that is occupied.

h. Flexible and adapt according to changing conditions quickly.

Knowledge possessed involves two different but interrelated components, namely content and skills. Content includes facts, ideas, principles, evidence and description of a process. In order to be well trained in providing content, an educator must have a deep understanding of the field of study being taught. The skills needed are skills that match the content can be seen in the following table 1 .

TABLE I. TABLE STYLES

\begin{tabular}{|l|l|l|}
\hline No & \multicolumn{1}{|c|}{ Skill } & \multicolumn{1}{c|}{ Description } \\
\hline 1 & $\begin{array}{l}\text { Communication } \\
\text { Skills }\end{array}$ & $\begin{array}{l}\text { Including reading, speaking and writing } \\
\text { continuously and clearly. In this case you need } \\
\text { to add communication skills on social media, } \\
\text { make YouTube videos, the ability to convey } \\
\text { ideas through the internet, and identify trends } \\
\text { and ideas from various parts of the world. } \\
\text {. }\end{array}$ \\
\hline 2 & $\begin{array}{l}\text { Study } \\
\text { independently }\end{array}$ & $\begin{array}{l}\text { Have the responsibility to find out and where } \\
\text { to find the knowledge needed. Learners can } \\
\text { learn new things such as new equipment, new } \\
\text { ways of doing things or learning from anyone } \\
\text { about what is needed }\end{array}$ \\
\hline
\end{tabular}




\begin{tabular}{|l|l|l|}
\hline No & \multicolumn{1}{|c|}{ Skill } & \multicolumn{1}{c|}{ Description } \\
\hline 3 & $\begin{array}{l}\text { Ethics and } \\
\text { Responsibilities }\end{array}$ & $\begin{array}{l}\text { Needed to build trust especially in informal } \\
\text { social networks. But this also applies generally } \\
\text { because ethics and responsibility generally } \\
\text { need to be known and applied according to } \\
\text { different places and conditions. }\end{array}$ \\
\hline 5 & $\begin{array}{l}\text { Teamwork and } \\
\text { flexibility }\end{array}$ & $\begin{array}{l}\text { Although it must be independent, } \\
\text { collaboration and teamwork are important to } \\
\text { share the same vision and help each other }\end{array}$ \\
\hline 5 & Critical thinking & $\begin{array}{l}\text { Needed to solve problems, be creative and } \\
\text { help strategize. This is important because new } \\
\text { products are emerging rapidly, new forms of } \\
\text { service and processes that can reduce costs } \\
\text { and increase competitiveness. Critical thinking } \\
\text { skills can help someone to solve all problems } \\
\text { without problems }\end{array}$ \\
\hline 7 & $\begin{array}{l}\text { In time, most knowledge-based activities will } \\
\text { depend on the use of technology. For example, } \\
\text { the radiologist knows how to use a new } \\
\text { technology that reads and analyzes the MRI } \\
\text { scan or the } \text { OJEG worker becomes an online } \\
\text { ojeg. Thus the use of digitasl technology needs } \\
\text { to be integrated with knowledge }\end{array}$ \\
\hline Kigital Skills & $\begin{array}{l}\text { Knowledge is changing very rapidly with } \\
\text { research, new developments and accelerating } \\
\text { the spread of ideas through the internet. Thus } \\
\text { knowledge will become obsolete. Knowledge } \\
\text { management becomes a key skill by finding, } \\
\text { evaluating, analyzing, applying and } \\
\text { disseminating information in certain contexts. }\end{array}$ \\
\hline
\end{tabular}

Skills development is based more on context, meaning that it is in line with knowledge. For example solving problems in early childhood education will certainly be different from students in secondary schools. In addition students need practice and good practice in order to achieve skills mastery and be consistent in its implementation. Students need feedback in every skill they learn so they can correct mistakes or explore new ideas.

In order for students to get the knowledge and skills that are able to help them face the era of disruption and the era of abundance, the teacher needs to change the way of teaching in accordance with their roles and functions. Learning can be done using the principle of connectivity so that it is able to present a learning model that recognizes major changes in society because learning is no longer an internal activity but can be done outside of oneself. The principles of connectivity in learning are [7]:

a. Learning and knowledge rests on diversity of opinions

b. Learning is a process of connecting sources of information.

c. In the learning process the teacher (human) is not the only one who can provide knowledge. Learning can be through non-human appliances.

d. Learning must be able to increase knowledge capacity that is greater than what is known at this time. e. Fostering and maintaining the connections needed to facilitate sustainable learning.

f. Learning is able to see the relationship between fields of science, ideas and concepts so that they become core skills.

From time to time changes in teaching depend on technology. In the last ten to fifteen years technology has increasingly influenced teaching activities. This trend can be seen in the presence of full online learning, mixed learning between face to face and online, open learning, and Massive Open Online Courses (MOOCs). MOOCs is a very effective technology because it is a lesson that can be downloaded, studied by anyone, everywhere and is free and does not require classrooms. There are traditional teaching materials made by films that are able to create a forum which is an interactive user community between students, instructors and assistants. MOOCs are developments and updates of distance learning and are one of the products of the era of abundance.

Teachers in facing the era of disruption and the era of abundance inevitably must be smart and master technology. Remember philosophy is guided and imitated, so if you want students to master technology, the teacher must be willing to change and always up to date reading a lot, renewing knowledge, being able to manage classes online, do construction, search and find new ones $[8,9]$ However it is difficult to replace the role of the teacher with artificial intelligence as long as the teacher continues to improve competence and see challenges as opportunities [10]. So, no matter how sophisticated the teacher is, it still has to emphasize its main task, which is forming good character for students [11].

\section{CONCLUSION}

The current disruption era is seen as one of the eras which presents new opportunities, disrupts existing jobs and replaces people with technology or even technology with technology. The emergence of the disruption era also gave rise to an era of abundance, where everything can be accessed easily and cheaply without being limited by the space and walls of the class. In this case the teacher is required to construct creativity, thought, cooperation and technology. Teacher competency must be supplemented with social, cognitive and technical behavioral competencies. By changing the way to educate and learn to teach, the world of education in the future will have considerable difficulties. Teachers cannot compete with technology. Google has taken over as a source of learning so it is feared that knowledge possessed by students is not able to compete with technology and changing times. However, the existence of teachers cannot be replaced because students still need ethical, cultural, social skills and empathy values that cannot be taught by machines. 
[5] O. Hamalik, Kurikulum dan Pembelajaran, Jakarta: Bumi Aksara, 2013.

[6] A. (. Bates, Teaching in a Digital Age: Guidelines for Designing Teaching and Learning, 2015.

[7] G. Siemens, "Connectivism: a Theory for the Digital Age," eLearningSpace, 2004.

[8] Wartomo, "Peran Guru dalam Pembelajaran Era Digital," in Temu Ilmiah Nasional Guru (TING) VIII, Jakarta, 2016.

[9] A. Kuswantoro, "Guru Menyambut Era Disrupsi," 2018. [Online]. Available: https://unnes.ac.id/gagasan/guru-menyambut-eradisruption/.

[10] Rustono, Interviewee, Peran Pendidik Tak Tergantikan di Era Disrupsi dan Revolusi Industri 4.0. [Interview]. 3 Mei 2018.

[11] K. S. Subagya, "Guru Era 4.0," 9 Maret 2018. [Online]. Available: https://krjogja.com/web/news/read/59981/Guru_Era_4_0. [Accessed Februari5 2019].

[4] UU RI Nomor 14, Guru dan Dosen, Jakarta: Pemerintah Republik Indonesia, 2005. 